\title{
REDISTRIBUIÇÃO DO ONUS PROBANDI NO PROCESSO DO TRABALHO DIANTE DO NOVO CPC: IMPACTOS DA DISTRIBUIÇÃO DINÂMICA DO ÔNUS DA PROVA NA RESPONSABILIZAÇÃO DO ADMINISTRADOR PÚBLICO EM DEMANDAS ENVOLVENDO TERCEIRIZAÇÃO
}

\author{
BREAKDOWN OF PROBANDI ONUS IN THE LABOR PROCESS BEFORE THE \\ NEW CPC: THE DYNAMIC IMPACTS DISTRIBUTION OF THE BURDEN OF \\ PROOF IN HOLDING THE PUBLIC ADMINISTRATOR IN CLAIMS INVOLVING \\ OUTSOURCING
}

${ }^{1}$ Fábio Gabriel Breitenbach

${ }^{2}$ Sergio Torres Teixeira

\section{RESUMO}

O Supremo Tribunal Federal, ao apreciar o mérito da Ação Direta de Constitucionalidade $\mathrm{n}^{\mathbf{0}}$ 16 , declarou a constitucionalidade do $\S 1^{\circ}$, do artigo 71 , da Lei $\mathrm{n}^{\circ} 8.666 / 73$. Em face disso, no âmbito do Tribunal Superior do Trabalho, o resultado foi a edição de uma nova redação ao texto do inciso IV da sua Súmula 331, e, ainda, a inclusão de dois novos incisos (o V e o VI), um dos quais dedicado especificamente a disciplinar a responsabilidade patrimonial decorrente da terceirização no âmbito do serviço público. Foi consagrada a tese acerca da responsabilidade subsidiária e subjetiva do ente administrativo pelos créditos trabalhistas devidos ao empregado prestador de serviços terceirizados no âmbito da administração pública direta e indireta. Diante deste novo contexto, a responsabilização do administrador público decorrerá de duas condições: a) o inadimplemento das obrigações trabalhistas por parte da empresa prestadora de serviços terceirizados; e b) o descumprimento culposo do tomador dos serviços quanto às obrigações previstas da Lei $\mathrm{n}^{\circ} 8.666 / 93$, notadamente no tocante à fiscalização do adimplemento das obrigações contratuais e legais da empresa interposta como empregadora. Nesse quadro, ganhou certo relevo a discussão sobre a quem incumbe processualmente comprovar os elementos necessários para responsabilização do administrador público. Pois bem. Considerando as peculiaridades que cercam o quadro fático envolvendo uma relação triangular de terceirização, na qual a tomadora de serviços é uma entidade da administração pública direta ou indireta, os fundamentos da teoria da distribuição dinâmica do ônus da prova e do princípio da aptidão para a prova não deixam dúvidas: é do administrador público o ônus de provar a regularidade da contratação dos serviços pela empresa e a existência da regular e adequada fiscalização do cumprimento das obrigações trabalhistas por parte desta última perante os seus empregados que prestavam serviços ao ente da administração pública direta ou indireta. Será analisado, pois, como o ordenamento atual, bem como a legislação cuja vigência se aproxima, ou seja, o novo CPC (Lei no 13.105, de 2015), podem ser utilizados para justificar a distribuição dinâmica do ônus da prova.

Palavras-chave: Terceirização de serviços, Administração pública, Distribuição dinâmica do ônus da prova, Novo código de processo civil

\footnotetext{
${ }^{1}$ Mestrando em Direito, pela Universidade Católica de Pernambuco -UNICAP, Pernambuco (Brasil). Professor na Universidade do Estado da Bahia - UNEB, Bahia (Brasil). E-mail: fabiogabrielb@gmail.com

2 Doutor em direito pela Universidade Federal de Pernambuco - UFPE, Pernambuco (Brasil). Professor da Universidade Federal de Pernambuco - FDR/UFPE e da UNICAP, Pernambuco (Brasil). E-mail: sergiotteixeira@uol.com.br
} 


\begin{abstract}
The Supreme Court, in considering the merits of the Direct Action of Constitutionality 16, declared the constitutionality of $\S 1^{\circ}$ of Article 71 of Law 8.666/73. Given that, under the Superior Labor Court, the result was the publication of a new wording to the text of section IV of its Precedent 331, and also the inclusion of two new paragraphs (V and VI), with paragraph $\mathrm{V}$ being specifically dedicated to discipline the equity liability of outsourcing within the public service. With those precedents, the thesis about joint and subjective liability of the the administrative entity for labor credits owed to the employee provider of outsourced services was finally established. Given this new context, the accountability of public administrator will take place on two conditions: a) the breach of labor obligations on the part of the provider of outsourced services; and b) the negligent failure of the borrower of services as the obligations of Law 8.666/93, notably as regards the supervision of the due performance of contractual and legal obligations of the company filed as an employer. In this framework, what gained certain importance was the discussion of who bears procedurally prove the necessary elements for accountability of the public administrator. Considering the peculiarities surrounding the factual framework involving a triangular relationship of outsourcing, in which the borrower of services is an entity of the public administration, the fundamentals of the theory of dynamic distribution of the burden of proof and the principle of the better aptitude to prove leaves no doubt: the public administrator assumes the burden of proving the correctness of the selection of services by the company and the existence of regular and adequate enforcement of labor obligations by the latter towards its employees who provided services to the entity within the public administration. The present text will be analyzing the current procedural system, as well as the new model of procedural legislation whose term approaches, that is, the new Code of Civil Procedure (Federal Law 13.105/15), and how can the new system be used to support the dynamic allocation of the burden of proof.
\end{abstract}

Keywords: Outsourcing services, Public administration, Dynamic distribution of the burden of proof, New code of civil procedure 


\section{INTRODUÇÃO}

Ônus da prova é o encargo que se atribui a uma das partes no litígio de demonstrar as alegações de fato que formulou. Tal encargo pode ser atribuído pela lei, pelo magistrado ou por convenção das partes.

A distribuição do ônus da prova é um dos elementos de maior relevância na fase cognitiva de um processo judicial. Como, no âmbito das demandas contenciosas, a simples alegação de um fato por uma das partes não é suficiente, per si, para definir a convicção do julgador, sendo necessário comprovar o respectivo quadro empírico afirmado, a definição do encargo probatório é imprescindível à dinâmica da demanda litigiosa.

A lei prevê abstratamente quem arca com a falta de prova sobre o fato alegado, isso porque antevê ser possível que as provas produzidas pelas partes sejam insuficientes para revelar a verdade dos fatos. Tal técnica decorre, assim, da vedação ao non liquet (CPC atual, art. 126; novo CPC, art. 140), na medida em que ao juiz é imposto o dever de julgar, mesmo que sem prova.

Nessa perspectiva, as regras sobre a distribuição do ônus da prova são dirigidas ao juiz, pois indicam qual das partes suportará as consequências negativas decorrentes da ausência, ao final da fase instrutória - na qual, ressalte-se, às partes devem ser assegurados o direito fundamental à produção de provas úteis e necessárias para comprovação dos fatos alegados, pois isso decorre do princípio do devido processo legal -, de um determinado elemento de prova.

Mas como se desenvolve tal técnica de repartição do encargo probatório. Essencialmente, a quem incumbe provar o fato? Depende; e depende de uma série de questões. Qual parte afirmou a existência do fato? Qual a natureza do fato afirmado, se constitutivo de um direito ou obstativo a este? E a dificuldade ou facilidade de se produzir uma prova; pode ser considerada pelo magistrado para fins de atribuição do respectivo onus probandi?

A discussão se torna ainda mais interessante quando examinada à luz de uma polêmica recorrente no âmbito dos tribunais do trabalho: a definição de a quem incumbe demonstrar a existência de culpa (in vigilando ou in eligendo) do administrador público tomador de serviços terceirizados, quando postulada a sua responsabilização subsidiária pelos créditos devidos ao trabalhador em virtude da inadimplência da empresa prestadora dos serviços.

O presente texto almeja examinar tal polêmica sob um olhar crítico, analisando tanto o quadro atual (ainda sob a influência do complexo normativo obtido mediante a aplicação do 
artigo 818 consolidado e, supletivamente, do artigo 333 do atual Código de Processo Civil), como as perspectivas futuras, decorrentes da promulgação da Lei 13.105, de 2015, e, como consequência, do cada vez mais próximo início da vigência de um novo Código de Processo Civil.

Desenvolver um debate crítico acerca da repartição do ônus da prova diante de tais lides no cenário contemporâneo e naquele em breve a ser impactado pela vigência de um novo diploma processual, portanto, constitui a linha de raciocínio a ser desenvolvido nas próximas páginas.

A metodologia empregada, no que tange à tipologia, foi a pesquisa bibliográfica, e, em relação ao método, foi utilizada a lógica hipotético-dedutiva e analógica. O texto está estruturado em três tópicos principais. No primeiro momento, apresentaremos o debate sobre a necessidade de ser demonstrada a existência de culpa do tomador de serviços como condição para a sua responsabilização patrimonial diante do trabalhador terceirizado. Na sequência, será abordada a repartição do ônus da prova segundo a atual disciplina legal, isso com vistas a verificar como ocorrerá a demonstração da culpa in eligendo ou in vigilando do tomador dos serviços. Depois, abordaremos a técnica de repartição do ônus da prova trazida pelo novo CPC, buscando esclarecer de quem é o encargo de demonstrar a culpa do administrador público que atua como tomador de serviços. Ao final, serão apresentadas as conclusões possíveis.

\section{A EXISTÊNCIA DE CULPA DO TOMADOR DE SERVIÇOS COMO CONDIÇÃO PARA A SUA RESPONSABILIZAÇÃO PATRIMONIAL DIANTE DO TRABALHADOR TERCEIRIZADO}

Em pronunciamento jurisdicional (acórdão publicado no dia 08.09.2011), o Supremo Tribunal Federal, ao apreciar o mérito da Ação Direta de Constitucionalidade $n^{\circ}$ 16, declarou a constitucionalidade do $\S 1^{\circ}$, do artigo 71 , da Lei $n^{\circ} 8.666 / 73$. O texto do mencionado artigo, com seus parágrafos, é o seguinte:

\footnotetext{
Art. 71. O contratado é responsável pelos encargos trabalhistas, previdenciários, fiscais e comerciais resultantes da execução do contrato.

$\S 1^{\circ} \mathrm{A}$ inadimplência do contratado com referência aos encargos trabalhistas, fiscais e comerciais não transferem à Administração Pública a responsabilidade por seu pagamento, nem poderá onerar o objeto do contrato ou restringir a regularização e o uso das obras e edificações, inclusive perante o registro de imóveis.

$\S 2^{\circ}$ A administração pública responde solidariamente com o contratado pelos encargos previdenciários resultantes da execução do contrato, nos termos do artigo 31 da lei 8.212, de 24/07/91.
} 
O pronunciamento do STF, ao reconhecer a constitucionalidade do respectivo dispositivo, acabou impondo uma mudança no entendimento, até aquele momento consolidado, no âmbito da Justiça do Trabalho, envolvendo uma responsabilidade objetiva do tomador dos serviços terceirizados (seja este da iniciativa privada ou não), por implicar numa interpretação restritiva acerca da responsabilização do ente da administração pública diante da inadimplência de créditos trabalhistas devidos ao empregado que prestou serviços terceirizados àquele.

Ao estipular que "a inadimplência do contratado com referência aos encargos trabalhistas, fiscais e comerciais não transferem à Administração Pública a responsabilidade por seu pagamento", o $\S 2^{\circ}$, do artigo 71, da Lei $n^{\circ} 8.66 / 93$, acaba por impedir a incidência de uma responsabilidade patrimonial objetiva do tomador de serviços terceirizados no âmbito do serviço público. A responsabilização da entidade administrativa, portanto, não mais pode ocorrer pelo simples não pagamento das verbas laborais devidas ao obreiro. Tal inovação jurisprudencial, entretanto, não afastou por completo a possibilidade de responsabilização da entidade da administração pública direta e indireta.

Nesse contexto, correta a interpretação manifestada expressamente pelo Ministro Cézar Peluso, quando dos debates travados durante o julgamento da ADI $n^{\circ} 16$, pelo STF, que enfatizou explicitamente que a declaração de constitucionalidade do artigo 71 da Lei $\mathrm{n}^{\circ}$ 8.666/93 “(...) não impedirá que a Justiça do Trabalho recorra a outros princípios constitucionais e, invocando fatos da causa, reconheça a responsabilidade da Administração, não pela mera inadimplência, mas por outros fatos".

Tal pronunciamento, por sua vez, consolidou um espaço para uma interpretação, conforme a Constituição, do respectivo dispositivo, assegurando a prevalência de valores constitucionais como o da dignidade da pessoa humana do trabalhador e do valor social do trabalho (artigo $1^{\circ}$ da CRFB/88), no sentindo de admitir, se não a responsabilidade objetiva, ao menos a responsabilidade patrimonial subjetiva do ente administrativo tomador de serviços terceirizados.

A nova posição do STF, assim, não resultou na criação de um novo "escudo impenetrável” como a vedação à formação de um vínculo direto entre o trabalhador e a entidade da administração pública direta ou indireta nos moldes previstos no inciso II da Súmula 331 do TST, mas, sim, num procedimento de mitigação resultante no reconhecimento de uma responsabilidade baseada na culpabilidade do respectivo tomador dos serviços 
terceirizados, atenuando, mas não eliminando, os efeitos do princípio da despersonalização do empregador.

No âmbito do Tribunal Superior do Trabalho, o resultado foi a edição de uma nova redação ao texto do inciso IV da sua Súmula 331, e, ainda, a inclusão de dois novos incisos (o $\mathrm{V}$ e o VI), um dos quais dedicado especificamente a disciplinar a responsabilidade patrimonial decorrente da terceirização no âmbito do serviço público. O conteúdo das respectivas normas sumulares, aprovado pela Resolução 127, de 2011, e publicado no Diário da Justiça de 27.05.2011, é o seguinte:

IV - O inadimplemento das obrigações trabalhistas, por parte do empregador, implica a responsabilidade subsidiária do tomador dos serviços quanto àquelas obrigações, desde que haja participado da relação processual e conste também do título executivo judicial.

V - Os entes integrantes da Administração Pública direta e indireta respondem subsidiariamente, nas mesmas condições do item IV, caso evidenciada a sua conduta culposa no cumprimento das obrigações da Lei n. ${ }^{\circ}$ 8.666, de 21.06.1993, especialmente na fiscalização do cumprimento das obrigações contratuais e legais da prestadora de serviço como empregadora. A aludida responsabilidade não decorre de mero inadimplemento das obrigações trabalhistas assumidas pela empresa regularmente contratada.

VI - A responsabilidade subsidiária do tomador de serviços abrange todas as verbas decorrentes da condenação referentes ao período da prestação laboral.

O exame dos respectivos enunciados revela que, enquanto o texto e o alcance do inciso IV ficaram menores, limitados às entidades da iniciativa privada, e o novo inciso VI estabeleceu uma proporcionalidade à responsabilidade patrimonial do tomador vinculada ao período da prestação de serviços à sua pessoa, o novo inciso $\mathrm{V}$ disciplinou precisamente a responsabilidade patrimonial das entidades da administração pública direta e indireta, enquanto tomadores de serviços terceirizados.

Restou consagrada no inciso V da Súmula 331 do TST, assim, a tese acerca da responsabilidade subsidiária e subjetiva do ente administrativo pelos créditos trabalhistas devidos ao empregado prestador de serviços terceirizados no âmbito da administração pública direta e indireta. Noutras palavras, a responsabilização do administrador público decorrerá de duas condições: a) o inadimplemento das obrigações trabalhistas por parte da empresa prestadora de serviços terceirizados; e b) o descumprimento culposo do tomador dos serviços quanto às obrigações previstas da Lei $n^{\circ}$ 8.666/93, notadamente no tocante à fiscalização do adimplemento das obrigações contratuais e legais da empresa interposta como empregadora.

Em um processo trabalhista, portanto, a responsabilização patrimonial subsidiária da entidade da administração pública direta ou indireta, pelos créditos trabalhistas devidos ao obreiro, estará diretamente vinculada à demonstração da existência de culpa in eligendo ou, mais frequentemente, da culpa in vigilando do administrador público. Para fins de responsabilização deste, portanto, deverá ser evidenciada falha na contratação da empresa 
prestadora dos serviços terceirizados ou, o que é mais comum, descumprimento do dever do administrador público de fiscalizar o correto adimplemento das obrigações patronais por parte da empresa prestadora de serviços terceirizados.

Exemplo da primeira espécie de culpa (a in eligendo), relativa à escolha da prestadora dos serviços, é a contratação de uma empresa inidônea, sem o devido processo licitatório, ou então por meio de um licitação falha ou "viciada", dirigido a uma empresa tecnicamente incapaz ou economicamente débil. Exemplo da segunda modalidade de culpa (a in vigilando) é a falta de fiscalização (por parte do administrador público) quanto ao pagamento dos salários mensais dos empregados pela empresa interposta, ou a ausência de averiguação quanto à regularidade do adimplemento das obrigações relativas ao recolhimento de depósitos do FGTS ou contribuições previdenciárias.

Pois bem. A Lei $n^{\circ}$ 8.666/93 estabelece uma série de diretrizes legais cuja observância é essencial à validade de qualquer contratação feita pelo administrador público, inclusive no que tange ao estabelecimento de vínculo contratual com uma empresa prestadora de serviços terceirizados. O seu artigo 23 estabelece as espécies de licitação e os artigos seguintes estabelecem a respectiva disciplina de desenvolvimento, inclusive a previsão das hipóteses restritas de sua dispensa, elencadas no seu artigo 24. Qualquer desvio ou omissão quanto a tal disciplina legal poderá ensejar a culpa in eligendo da entidade administrativa, fazendo surgir a sua responsabilidade patrimonial subjetiva quanto aos títulos laborais devidos ao empregado da empresa prestadora dos serviços.

O artigo 67 da mesma Lei, por sua vez, é igualmente preciso quanto à imposição do dever de fiscalizar por parte do administrador público. Inclusive, impõe a obrigação do administrador público de acompanhar a execução do contrato administrativo por meio de um representante da Administração especialmente designado para tal fim, com a possibilidade de contratação de terceiros para auxílio, e o dever de anotar em registro próprio todas as ocorrências relacionadas à execução do respectivo contrato.

Nesse cenário, qualquer inércia diante de tal dever de fiscalizar, por sua vez, igualmente enseja a responsabilização do administrador públicos pelos títulos laborais devidos ao empregado da empresa interposta. A omissão, na hipótese, se revela uma falha intolerável diante das diretrizes protecionistas consubstanciadas na diretriz jurisprudencial da Súmula 331 do TST, uma vez que tal descumprimento do dever de fiscalizar expõe o trabalhador hipossuficiente a um quadro de vulnerabilidade diante de empresas inescrupulosas ou simplesmente incompetentes. 
Há como, portanto, assegurar a tutela ao empregado que presta serviços terceirizados à administração pública direta ou indireta, mesmo diante de uma interpretação mais restritiva da responsabilidade do administrador público diante do inadimplemento de obrigações laborais pela empresa interposta. Mas, para tanto, é necessária a caracterização da conduta culposa daquele.

Demonstrada, pois, a culpa in eligendo ou in vigilando, haverá a responsabilização subsidiária do administrador público quando for caracterizado um quadro de inadimplência da empresa prestadora dos serviços. Mas a questão nuclear, dentro do respectivo contexto, é como demonstrar tal quadro de culpabilidade. A quem incumbe demonstrar tal culpabilidade? Como ocorre a respectiva distribuição do ônus da prova? É esta a questão que será abordada a seguir.

\section{REPARTIÇÃO DO ÔNUS DA PROVA SEGUNDO A ATUAL DISCIPLINA}

\section{LEGAL E A DEMONSTRAÇÃO DA CULPA IN ELIGENDO OU IN VIGILANDO DO TOMADOR DE SERVIÇOS}

No âmbito da legislação processual do trabalho, a distribuição do ônus da prova encontra a sua disciplina nas singelas letras do artigo 818 da Consolidação das Leis do Trabalho: “A prova das alegações incumbe à parte que as fizer". A simplicidade do texto legal, no entanto, não deve enganar o intérprete. Mesmo diante da objetividade das letras, o operador do direito não pode se restringir a uma interpretação literal do conteúdo do respectivo enunciado normativo. No processo interpretativo do citado dispositivo, é imprescindível adotar uma hermenêutica processual compatível com a finalidade do respectivo regramento.

Dentro deste contexto, ao estabelecer, no artigo 818, que compete a cada litigante demonstrar a veracidade de suas próprias afirmações, o legislador não está estabelecendo que, em face de qualquer alegação feita por uma das partes, será desta a incumbência de comprovar a respectiva assertiva, sem exceção. Em alguns casos, a peça contestatória da parte ré se limita a negar a existência do quadro fático afirmado pela parte autora, sem alegar qualquer outro fato concreto e obstativo à pretensão da parte demandante. Nesse sentido, por exemplo, a defesa de um reclamado que se limita a negar a existência de qualquer vínculo de emprego com o reclamante, sem entrar em detalhes ou mesmo apontar qualquer fato obstativo à pretensão do postulante. 
Noutros casos, a contestação do réu não se restringe a simplesmente negar a existência do fato sustentando pelo autor, mas faz a exposição de um quadro fático completamente distinto do narrado da peça vestibular, com o demandado afirmando existir uma série de outros fatos (modificativos, impeditivos ou extintivos) distintos do fato afirmando pelo demandante, com o objetivo de obstar a pretensão autoral. É o caso, por exemplo, de uma peça contestatória na qual a reclamada não se limita a simplesmente negar a existência de uma relação de emprego com a reclamante, mas afirma categoricamente que a respectiva autora foi na realidade uma simples estagiária, ou então que a mesma manteve na realidade uma relação de trabalho autônomo com a ré, atuando como uma trabalhadora autônoma. Neste último exemplo, a alegação da ré atrai para a própria demandada o encargo de demonstrar a veracidade de sua afirmação acerca do respectivo quadro fático.

A disciplina do artigo 818 da CLT, por conseguinte, deve ser compreendida à luz do regramento tecnicamente mais apurado, previsto no artigo 333 do atual Código de Processo Civil (Lei n $\left.{ }^{\circ} 5.869 / 73\right)$, cujo conteúdo é de uma precisão exemplar:

Art. 333. O ônus da prova incumbe:

I - ao autor, quanto ao fato constitutivo do seu direito;

II - ao réu, quanto à existência de fato impeditivo, modificativo ou extintivo do direito do autor.

Com base em tal conteúdo normativo, resta definido que o encargo probatório de cada parte se vincula ao elenco de afirmações fáticas positivas constantes da sua respectiva peça processual. Se afirmado um fato "positivo", ou seja, um fato concreto demonstrável mediante a produção de provas aptas a sustentar a sua existência, a parte (autor ou réu, reclamante ou reclamado) que fez a respectiva afirmação assumirá o encargo de convencer o magistrado acerca da ocorrência do respectivo fato. Seja um fato constitutivo afirmado pelo autor, seja um fato obstativo sustentando pelo réu, o ônus de provar recairá sobre aquele que fez a respectiva afirmação positiva (LEITE, 2011, p. 599).

Por outro lado, se a parte ré, ao contestar uma postulação formulada pela parte autora, expõe uma "negativa genérica" (também conhecida como "negativa simples" ou mesmo "fato negativo"), apenas desmentindo a existência do fato sustentando pelo demandante, sem nada acrescentar quanto ao quadro fático apontado pelo postulante, o encargo probatório permanecerá com este autor, a quem competirá convencer o juízo acerca da existência dos fatos constitutivos afirmados na petição inicial.

Nesse sentido, se o réu simplesmente disser que "nunca viu o autor praticando tal ato ou executando tal atividade", contrariando o fato constitutivo afirmado pelo autor na peça vestibular pela simples negativa da sua ocorrência, refutando a sua existência sem apontar 
qualquer outro fato concreto em contraposição ao primeiro, incumbirá ao demandante demonstrar a efetiva prática da atividade cuja existência foi simplesmente negada pelo seu adversário, não sendo razoável atribuir o ônus ao demandado, pois, se assim fosse, teria que produzir provas aptas a confirmar que, durante a extensão da vida do autor, este jamais praticou o citado ato.

Para parte da doutrina, exigir a prova de algo que não ocorreu constitui um exemplo da chamada "prova diabólica", em virtude de sua produção ser impossível ou extremamente difícil. (DIDIER JR., BRAGA e OLIVEIRA, 2014). Com efeito, não se revela razoável atribuir a quem genericamente afirmou a inocorrência de um fato, assim, o encargo de provar tal quadro negativo de inexistência, pois envolve uma negativa "absoluta" ("indefinida" ou “indeterminada"), sem precisão no plano temporal ou no âmbito espacial. Se, no entanto, a respectiva negativa não for genérica em tais moldes, mas sim "qualificada" ou "determinada", materializada numa negativa cujo contraponto é um fato positivo perfeitamente sujeito à prova, é perfeitamente admissível atribuir à parte que negou a existência do respectivo fato o ônus de provar o corresponde fato positivo.

Exemplificando, se postuladas diferenças salariais pelo autor e na resposta do réu este negar a existência de tais diferenças, a respectiva negativa relativa pode sim ser objeto de prova, sendo ônus do demandado comprovar o correto pagamento dos salários devidos (fato positivo correspondente ao fato negativo exposto na contestação).

Apenas uma negativa genérica ou absoluta do demandado, assim, impede que encargo probatório acerca da inocorrência do fato seja atribuído ao réu. Agora, se o demandado expuser na sua defesa uma afirmação fática segundo a qual o autor sempre exerceu de forma integral uma outra atividade específica não reconhecida na peça vestibular, logicamente recairá sobre o demandado o ônus de demonstrar tal quadro fático obstativo à pretensão do demandante. Nesse sentido, aliás, o inciso VI da Súmula 06 do colendo TST: “É do empregador o ônus da prova do fato impeditivo, modificativo ou extintivo da equiparação salarial”, ao tratar da distribuição do ônus da prova em ações que tenham por objeto a pretensão à isonomia salarial entre paradigma e paragonado.

Pode parecer estranha a admissibilidade de uma disciplina própria do Código de Processo Civil no âmbito do processo do trabalho quando já existente na legislação processual do trabalho um regramento explícito (o artigo 818 da CLT). Contudo, é relevante destacar que a aplicação da disciplina do artigo 333 do atual CPC na seara do processo laboral ocorre de forma supletiva e não subsidiária. Ou seja, não em decorrência de uma omissão legislativa 
(aplicação subsidiária em face da lacuna que deve ser suprida), mas sim em virtude da necessidade de complementar uma normatização ainda abstrata e/ou incompleta (aplicação supletiva em face da necessidade de complementação normativa), com a finalidade de proporcionar uma disciplina mais densa, mais precisa e mais em sintonia com os princípios do respectivo sistema normativo.

A aplicação supletiva das regras do Processo Comum no âmbito do Processo do Trabalho, apesar de não tratada no texto do artigo 769 da CLT (que prevê apenas a aplicação subsidiária), há muito é plenamente admitida como forma de aperfeiçoar o modelo processual trabalhista. E assim agiu o Tribunal Superior do Trabalho ao expressamente prever no mencionado texto sumular a aplicabilidade da disciplina do artigo 333 do atual CPC às demandas envolvendo pedidos de equiparação salarial. Ao assim agir, o órgão máximo do Judiciário do Trabalho está simplesmente admitindo a aplicação supletiva da disciplina do citado artigo 333 ao processo do trabalho, para complementar a disciplina normativa do artigo

818 da CLT. Isso, aliás, é o que o TST costuma fazer com vários outros institutos, dentre os quais se destaca o duplo grau obrigatório de jurisdição (Súmula 303 do TST, artigo $1^{\circ}$, inciso V, do Decreto-Lei 779/69 e artigo 475 do atual CPC).

A disciplina relativa à distribuição do ônus da prova previstas na legislação (artigos 818 da CLT e 333 do CPC atual), entretanto, corresponde a um conjunto regras dirigidas imediatamente às partes. Tal complexo estabelece uma atribuição a priori e objetivamente definida pelo legislador, sem considerar as peculiaridades de cada caso concreto, distribuindo para os litigantes os encargos probatórios que, se não forem observados a contento, fazem surgir um quadro de inconveniência e potencial prejuízo. Segundo a regra legal abstratamente definida, a ausência de provas aptas a convencer o juízo gera para a parte sobre a qual recaia o respectivo ônus probatório uma consequência naturalmente maléfica para o deslinde da demanda em seu favor: o alegado fato cujo reconhecimento era do seu interesse será reputado como inexistente pelo julgador. É um sistema fundado na ideia de uma distribuição estática do ônus da prova, com os encargos sendo definidos previamente e modo genérico e abstrato (MACÊDO e PEIXOTO, 2014, p. 151).

Diferente é a distribuição dinâmica do ônus da prova, feita pelo magistrado instrutor de um processo judicial, levando em consideração as peculiaridades do caso e a aptidão de cada parte para produzir a prova. Dentro de tal contexto, o juiz atribui os encargos probatórios de acordo com a capacidade de cada parte em produzir as provas, mesmo que tal atribuição venha a fugir das diretrizes da regra geral própria do sistema estático de distribuição do ônus probatório 
definido pelo legislador. A distribuição dinâmica pode até coincidir com a distribuição prevista em lei, mas é igualmente possível que o magistrado venha a atribuir o encargo de provar um fato a uma parte que, pela disciplina geral e abstrata do legislador, não teria tal ônus, invertendo este ao estabelecer tal alteração (PAMPLONA FILHO e SOUZA, 2013, p. 387).

É importante enfatizar que a distribuição do ônus da prova pelo magistrado não se confunde com a previsão legal de uma "inversão" de tal ônus em casos excepcionais. Na legislação processual brasileira existem hipóteses legais de "inversão" que não dependem exclusivamente da intervenção do magistrado. É que ocorre no âmbito das demandas envolvendo relações de consumo, diante da estipulação do artigo $6^{\circ}$, inciso VIII, do Código de Defesa do Consumidor (Lei $\mathrm{n}^{\circ}$ 8.078/90), que inclui dentre os direitos básicos do consumidor “a facilitação da defesa de seus direitos, inclusive com a inversão do ônus da prova, a seu favor, no processo civil, quando, a critério do juiz, for verossímil a alegação ou quando for ele hipossuficiente, segundo as regras ordinárias de experiências".

$\mathrm{Na}$ realidade, entretanto, o citado dispositivo do CDC não prevê uma verdadeira “inversão", pois tal técnica pressupõe que originalmente o encargo era de uma parte e depois foi redistribuído para a parte adversa. A regra do mencionado inciso VIII é, apenas, uma exceção à disciplina geral do artigo 333 do atual CPC, estabelecida previamente pelo próprio legislador. Não há "inversão", uma vez que, no caso concreto, o ônus jamais recaiu sobre uma parte e posteriormente foi deslocado para a outra. Desde o início, a incidência da regra ao caso excepcional estabeleceu, por obra do legislador, a distribuição de um encargo probatório a uma parte processual que, pela regra genérica, não o teria como seu.

A forma adequada de promover uma verdadeira inversão do ônus da prova é mediante a intervenção do juiz encarregado de conduzir a fase instrutória de processo judicial, promovendo a distribuição dos encargos probatórios de forma distinta daquela tipificada na regra genérica prevista em lei, no exercício dinâmico do seu poder diretivo. Desde que definido antes do julgamento da causa, em momento apto a permitir que os litigantes se amoldem à nova regra, resguardando as garantias constitucionais do processo relativas ao contraditório e à ampla defesa, é perfeitamente admissível o deslocamento do encargo probatório de uma parte para outra, quando devidamente fundamentada a decisão do magistrado em elementos que justifiquem tal alteração.

Uma das situações que autorizam tal distribuição dinâmica do ônus da prova ocorre quando, diante do caso concreto, o magistrado constata que uma das partes se apresenta em condições muito mais favoráveis para a produção da prova em comparação à outra que, pela 
regra geral, estaria encarregada de apresentar os elementos probatórios para firmar a convicção do juiz. O chamado princípio da aptidão para a prova, destarte, orienta o operador do direito no sentido de que se deve atribuir o ônus da prova à parte mais capacitada e aparelhada para produzir uma prova, mesmo que o encargo probatório originalmente seja de outra parte. Como o sistema abstrata e aprioristicamente definido pelo legislador não se revela apto a proporcionar, em determinadas situações, um processo judicial justo e equilibrado, a distribuição dinâmica do ônus da prova permite corrigir distorções e melhor tutelar situações inalcançadas pelo regramento geral.

Dentro de tal contexto, o juiz pode inverter a carga probatória quando entender que, no respectivo caso, tal forma de distribuição do ônus da prova se revela mais adequada às peculiaridades da demanda e mais apta a gerar um resultado em sintonia com valores e normas constitucionais que servem de fins e parâmetros para o próprio processo judicial. Assim, enquanto a disciplina geral definida pelo legislador quanto à distribuição estática do ônus da prova se dirige genérica e abstratamente a todos os litigantes, a distribuição dinâmica do ônus da prova, pelo magistrado, se direciona às partes em casos específicos nos quais a inversão da carga probatória proporciona maior equilíbrio entre os litigantes e aumenta a probabilidade de uma tutela jurisdicional efetiva (adequada, justa, útil).

E nas ações que tenham por objeto a responsabilização patrimonial subsidiária do tomador de serviços, sendo estas entidades da administração pública direta ou indireta, em relações trilaterais de terceirização? Sobre quem recai o ônus da prova em relação à demonstração da existência (ou inexistência) de culpa in eligendo ou da culpa in vigilando do administrador público? É do reclamante o encargo de provar a existência da respectiva culpa do tomador dos serviços? Ou incumbe ao administrador público comprovar a inexistência de sua culpa?

Considerando as peculiaridades que cercam o quadro fático envolvendo uma relação triangular de terceirização, na qual a tomadora de serviços é uma entidade da administração pública direta ou indireta, os fundamentos da teoria da distribuição dinâmica do ônus da prova e do princípio da aptidão para a prova não deixam dúvidas: é do administrador público o ônus de provar a regularidade da contratação dos serviços pela empresa e a existência da regular e adequada fiscalização do cumprimento das obrigações trabalhistas por parte desta última perante os seus empregados que prestavam serviços ao ente da administração pública direta ou indireta. 
O empregado/reclamante, ao postular em juízo a responsabilização subsidiária do administrador público/tomador dos serviços, naturalmente está partindo do pressuposto de que este último adotou uma conduta culposa quanto aos seus deveres relativos à contratação regular da empresa interposta e/ou à fiscalização do adimplemento das suas obrigações laborais. Como a prática revela que, no mais das vezes, a entidade administrativa se restringe a negar, na sua defesa, qualquer conduta culposa da sua parte, à primeira vista pode parecer que o ônus da prova, ao ser distribuído conforme o modelo estático do artigo 333 do atual CPC, recaria sobre o trabalhador demandante.

A demonstração de tal comportamento culposo, entretanto, não pode ser atribuída ao respectivo reclamante. Simplesmente não se apresenta como razoável tal constatação. Apenas o administrador público revela condições de produzir provas aptas a demonstrar a regularidade do processo licitatório que culminou com a contratação da empresa interposta, exibindo a documentação hábil a confirmar o respeito ao postulado do devido processo legal na seara da respectiva negociação administrativa.

Como encarregar o trabalhador de demonstrar uma irregularidade em um processo administrativo ao qual ele jamais teve acesso? Esta prova, se não é impossível, então é demasiadamente difícil, configurando um exemplo peculiar de "prova diabólica".

Somente este mesmo administrador se revela capaz de apresentar provas que revelem o correto cumprimento do seu dever de policiar a obediência à legislação trabalhista por parte desta mesma empresa interposta, mediante a apresentação de provas idôneas que confirmam que houve de fato tal acompanhamento e supervisão. O cumprimento do dever de fiscalizar, dentro de um contex to de razoabilidade, somente pode ser comprovado pelo próprio devedor de tal prestação revisional. Como atribuir o encargo probatório acerca da inexistência de tal cumprimento ao trabalhador? Simplesmente não é razoável exigir do empregado/trabalhador terceirizado a demonstração de inércia daquele (ou seja, um verdadeiro fato puramente negativo). Aí, sim, sem dúvida alguma, surge um exemplo de "prova diabólica"!

Em que pese a inconsistência da jurisprudência dos tribunais do trabalho, ainda carentes de uma uniformidade acerca da questão, é visível a tendência em reconhecer a plena aplicabilidade do princípio da aptidão para a prova aos casos envolvendo a responsabilização patrimonial do tomador de serviços terceirizados no âmbito da administração pública direta ou indireta, em virtude do quadro de desigualdade patente entre os litigantes e a maior capacidade do administrador público em produzir as provas necessárias à definição da matéria controvertida. 
Existiu ou não existiu culpa in vigilando ou in eligendo do administrador público diante do quadro de inadimplência da empresa interposta? Como apenas a própria entidade administrativa reúne reais condições de demonstrar o cumprimento dos seus deveres de contratar corretamente a empresa prestadora de serviços segundo um processo licitatório regular e de fiscalizar o cumprimento por esta das obrigações trabalhistas devidas em face aos seus empregados que prestam serviços ao tomador, a tal administrador público é que o magistrado deverá atribuir o ônus de provar o correto cumprimento dos seus deveres e, portanto, a inexistência do comportamento culposo que o TST entende como pressuposto de sua responsabilização.

\section{A TÉCNICA dE REPARTIÇÃO dO ÔNUS DA PROVA NO NOVO CPC E O ENCARGO DE DEMONSTRAR A CULPA DO ADMINISTRADOR PÚBLICO}

A Lei $\mathrm{n}^{\circ} 13.105$, de 2015, ao disciplinar a distribuição do ônus da prova, manteve, no caput do artigo 373, a mesma técnica já consagrada no artigo 333 do atual CPC. O texto do respectivo dispositivo do novo $\mathrm{CPC}$, na realidade, é uma repetição das letras do artigo 333 do CPC de 1973, antes reproduzido.

Em outras palavras, em princípio o encargo de provar continua sendo distribuído de forma objetiva e estática, independentemente de qualquer peculiaridade envolvendo o caso concreto, ou particularidade envolvendo as partes litigantes: incumbe ao autor provar o fato constitutivo do seu direito afirmado na exordial e ao réu provar o fato obstativo à pretensão do autor, conforme alegado na sua defesa. O novo CPC, no entanto, estabeleceu, no $\S 1^{\circ}$, do art. 373, uma técnica alternativa de distribuição, consagrando uma fórmula peculiar de aplicação da teoria da distribuição dinâmica do ônus da prova:

$\S 1^{\circ}$ Nos casos previstos em lei ou diante de peculiaridades da causa relacionadas à
impossibilidade ou à excessiva dificuldade de cumprir o encargo nos termos do caput ou à maior
facilidade de obtenção da prova do fato contrário, poderá o juiz atribuir o ônus da prova de modo
diverso, desde que o faça por decisão fundamentada, caso em que deverá dar à parte a
oportunidade de se desincumbir do ônus que lhe foi atribuído.

O respectivo dispositivo legal, assim, prevê três hipóteses nas quais a técnica de distribuição prevista no caput não deverá ser seguida. A primeira situação contida no $\S 1^{\circ}$, do art. 373, do novo CPC, na realidade, não constitui tecnicamente uma inversão do ônus da prova. O que ocorre é uma exceção à regra genérica do ônus da prova, pois a própria lei estabelece que, em certas situações, existirá uma distribuição do ônus da prova de forma diferente daquele regramento comum. A lei estabelece que, em determinadas situações, a parte que alega o 
fato está dispensada de prová-lo, cabendo à outra parte o ônus da prova de que o fato não ocorreu. Exemplo de tal estipulação legal excepcional é a regra contida no art.

38 do Código de Defesa do Consumidor.

A segunda hipótese tipificada no $\S 1^{\circ}$, do art. 373 do novo CPC, por sua vez, envolve exatamente uma inversão do ônus da prova, considerando a distribuição apontada de forma estática pelo caput. Ao autorizar o magistrado a repartir de forma diversa o encargo probatório quando o mesmo estiver diante de uma causa cujas peculiaridades impossibilitam ou tornam extremamente complexa a produção da prova, o legislador está admitindo de forma implícita a distribuição dinâmica do ônus da prova, pois está permitindo ao julgador que atribua o ônus da prova de forma diferente do previsto no modelo objetivo de repartição, considerando elementos subjetivos da causa para definir de forma mais adequada a incumbência de provar o fato litigioso.

$\mathrm{Na}$ mesma linha se encontra a terceira e última hipótese, relativa a uma situação peculiar na qual uma das partes, apesar de não ter o encargo segundo o modelo estático de distribuição, tem, na prática, uma grande aptidão para produzir a prova acerca do respectivo fato. Neste caso, assim, não seria a impossibilidade ou dificuldade de provar que levaria à inversão do encargo, mas, sim, a manifesta simplicidade que a outra parte teria para se desvencilhar da respectiva incumbência.

$\mathrm{O} \S 2^{\circ}$, do mesmo artigo 373 do novo CPC, entretanto, apenas veda tal distribuição diferenciada do ônus da prova quando o resultado da reversão é a impossibilidade ou extrema dificuldade da outra parte em se desvencilhar do novo encargo probatório. O novo CPC, assim, apresenta tal inovação legislativa, disciplinando de forma direta e imediata uma técnica de distribuição dinâmica, vinculada a elementos peculiares a cada caso, que, durante o império do CPC de 1973, somente obteve amparo na doutrina e, de forma mais restrita, na jurisprudência dos tribunais.

Pois bem. A segunda metade do $\S 1^{\circ}$, do artigo 373 do novo CPC estipula regras procedimentais que buscam materializar as garantias constitucionais da motivação do julgado, do contraditório e da ampla defesa, ao exigir que a definição pela distribuição dinâmica do ônus da prova seja formalizada em uma decisão incidental, devidamente fundamentada, e, após, sendo assegurada a ciência de tal inovação quanto à inversão da regra geral da distribuição estática, seja proporcionado ao respectivo litigante oportunidade de se desincumbir do seu "novo" encargo de provar. 
A referida disciplina normativa do novo $\mathrm{CPC}$, por conseguinte, se encontra em perfeita sintonia com os direitos fundamentais processuais e, ainda, está em perfeita harmonia com o princípio da aptidão para a prova. A parte que tem melhores condições de produzir a prova, pois, é quem deve arcar com o ônus respectivo. A aplicabilidade da nova técnica do artigo $373, \S 1^{\circ}$, da Lei ${ }^{\circ} 13.105$, de 2015 , ao processo do trabalho, inclusive, já restou assentada no Fórum Permanente de Processualistas Civil, que editou o enunciado $\mathrm{n}^{\mathbf{0}} 302$, in verbis:

302. (art. $373, \S \S 1^{\circ}$ e $2^{\circ}$; art. 15). Aplica-se o art. 373 , $\S 1^{\circ}$ e $2^{\circ}$, ao processo do trabalho, autorizando a distribuição dinâmica do ônus da prova diante de peculiaridades da causa relacionadas à impossibilidade ou à excessiva dificuldade da parte de cumprir o seu encargo probatório, ou, ainda, à maior facilidade de obtenção da prova do fato contrário. O juiz poderá, assim, atribuir o ônus da prova de modo diverso, desde que de forma fundamentada, preferencialmente antes da instrução e necessariamente antes da sentença, permitindo à parte se desincumbir do ônus que lhe foi atribuído.

Quais os impactos de tal novo regramento, por seu turno, nas demandas que discutem a responsabilização do administrador público que assumiu a posição de tomador de serviços terceirizados? Tanto nos casos nos quais se discute a existência de culpa in vigilando (ausência de fiscalização adequada por parte do tomador quanto ao adimplemento das obrigações trabalhistas pela empresa prestadora de serviços), como nos casos de alegada culpa in eligendo (falha na escolha da empresa interposta, quando o processo de licitação permitiu a eleição de uma empresa sonegadora de direitos trabalhistas), é evidente a maior aptidão do administrador público para produzir as provas necessárias para demonstrar que ocorreu a devida fiscalização e/ou a regular seleção da empresa prestadora dos serviços, bem como é inequívoca a quase impossibilidade de o empregado/trabalhador terceirizado produzir tais provas. Afinal, toda a documentação comprobatória da realização da fiscalização e da regularidade do processo licitatório está em poder do tomador dos serviços!

Nessa linha de raciocínio, não se pode olvidar, também, que o art. 67 da Lei $n^{\circ}$ 8.666/93 exige que a execução do contrato seja acompanhada e fiscalizada por um representante da administração especialmente designado para tal encargo, o qual anotará em registro próprio todas as ocorrências relacionadas com a execução do contrato, determinando o que for necessário à regularização das faltas ou defeitos observados (Lei nº 8.666/93, art. $\left.67, \S 1^{\circ}\right)$.

A nova disciplina a ser seguida quando da entrada em vigor do novo CPC, em março de 2016, assim, proporciona ao magistrado a possibilidade de, com base em dispositivos legais expressos aplicáveis de forma supletiva ao processo do trabalho, atribuir ao administrador público o ônus da prova quanto à existência ou não de culpa in vigilando ou in eligendo por 
qualquer um de dois caminhos: a) sob a tese de ser impossível ou muito difícil a produção de provas pelo autor; ou b) sob a tese de ser extremamente fácil para o administrador público produzir tais provas, simplesmente exibindo os documentos comprobatórios da regularidade da fiscalização e/ou do processo de seleção da empresa prestadora dos serviços.

Com tal amparo legal expresso, assim, não será necessário o grande esforço argumentativo atualmente desenvolvido pelos magistrados para, ainda sob o império da limitada técnica estática do atual CPC, justificar a distribuição dinâmica do ônus da prova em casos de responsabilização do administrador público, conforme demonstrado pela seguinte ementa:

\begin{abstract}
DIREITO DO TRABALHO E DIREITO PROCESSUAL DO TRABALHO. RECURSO ORDINÁRIO DA RÉ. ADMINISTRAÇÃO PÚBLICA. RESPONSABILIDADE SUBSIDIÁRIA. CULPA IN VIGILANDO. ÔNUS DA PROVA. CARACTERIZAÇÃO. SÚMULA Nº 331 DO COLENDO TST. ADC 16. O plenário do Colendo STF, ao apreciar a ADC $n^{\circ} .16$, chegou ao consenso de que na aplicação do item IV da Súmula $n^{\circ} .331$ do C. TST o julgador terá de investigar caso a caso se a inadimplência tem como causa principal a falha ou falta de fiscalização pelo órgão público contratante. A circunstância de ter sido o processo licitatório realizado em consonância com os ditames da Lei $n^{\circ}$. 8.666/93 não é, de per se, excludente da responsabilidade subsidiária do órgão estatal, na medida em que, ao contratar as empresas prestadoras de serviços, deve-se ater, em princípio, à idoneidade e capacidade financeira da contratada para evitar prejuízos futuros, bem assim proceder, mês a mês, de maneira rigorosa, à fiscalização dos encargos fiscais e trabalhistas. A responsabilidade subsidiária do tomador de serviços não decorre do reconhecimento do vínculo de emprego, mas, sim, do entendimento de que, na situação de terceirização de serviços, o contratante não se exime de atender os direitos sociais dos empregados do contratado, em caso de inadimplência da prestadora de serviços, em razão das culpas in eligendo ou in vigilando daquele. Na hipótese, enquanto os elementos constantes dos autos evidenciam a inexistência de culpa in eligendo, uma vez que restou demonstrada a regularidade da empresa contratada mediante processo licitatório regular, incumbia ao Juízo singular averiguar a existência ou não de omissão culposa do ente da Administração Pública, isto é, sua culpa e in vigilando. O ônus probatório acerca da demonstração de tal fato obstativo, por sua vez, evidentemente, recai sobre o próprio ente público em face às diretrizes do princípio da aptidão da prova. Somente o administrador público revela condições de produzir provas acerca de tal quadro fático, não sendo razoável exigir do empregado/trabalhador terceirizado a demonstração de inércia daquele (ou seja, um verdadeiro fato puramente negativo). E ao não se desincumbir do seu encargo probatório, inafastável a responsabilidade subsidiária, porque decorre da culpa in vigilando do ente público, amparado na aplicação analógica do art. 455 da CLT c/c a interpretação supletiva e sistemática dos artigos 186 e 927 do CC. Recurso a que se nega provimento.

Processo 0000047-03.2014.5.06.0321. TRT da 6 $6^{\mathrm{a}}$ Região. $1^{\mathrm{a}}$ Turma. Relator Desembargador Sergio Torres Teixeira. Publicado no Diário Oficial Eletrônico em 13.03.2015.
\end{abstract}

Além de proporcionar maior segurança para os jurisdicionados mediante o fornecimento de uma base legal expressa para justificar a distribuição diferenciada do encargo probatório, a imposição de regras procedimentais em perfeita sintonia com as garantias constitucionais do processo, relativos à motivação dos julgados, ao contraditório e à ampla defesa, por outro lado, acaba por beneficiar os próprios demandados, pois, a partir da vigência do novo CPC, ao administrador público estará assegurado o direito de ter ciência de uma decisão 
fundamentada na qual restou definida tal repartição distinta e, ainda, o direito de ser proporcionada uma oportunidade para produzir as provas aptas para demonstrar se, de fato e de direito, houve ou não culpa do respectivo tomador de serviços terceirizados.

A maior promessa da nova técnica disciplinada pelo artigo 373 do novo CPC, destarte, é exatamente esta: maior segurança para ambos os litigantes. A nova sistemática da Lei $\mathrm{n}^{\mathrm{0}}$ 13.105, de 2015, não representa a vitória de um lado e a derrota do outro. É, sim, uma conquista de todos, em prol da busca pela concretização da justiça.

\section{CONCLUSÕES}

A) A terceirização no âmbito do serviço se sujeita às regras especiais previstas na Súmula 331 do colendo TST, dentre as quais se inclui o condicionamento da responsabilização patrimonial subsidiária do tomador dos serviços à demonstração de conduta culposa deste;

B) Comprovada a culpa in eligendo, que ocorre quando existem defeitos no processo administrativo de escolha e contratação da empresa interposta, ou a culpa in vigilando, quando não existe a adequada fiscalização, pelo administrador público, do cumprimento das obrigações trabalhistas por parte da empresa interposta, a administração pública direta ou indireta responderá subsidiariamente pelos créditos devidos ao empregado que, contratado pelo prestador, prestou serviços ao respectivo tomador, desde que o ente da administração tenha participado da relação processual cognitiva e conste na sentença condenatória como responsável subsidiário.

C) Quanto ao sistema legal de distribuição do ônus da prova no âmbito do processo trabalhista, a regra geral é o modelo estático e abstrato, aplicável à generalidade das demandas, no qual o artigo 333 do atual CPC se revela aplicável de forma supletiva, complementando normativamente a regra mais abstrata prevista no artigo 818 da CLT;

D) Coexiste com o sistema estático de repartição do ônus da prova prevista pelo legislador e aplicável no processo do trabalho, entretanto, o sistema da distribuição dinâmica do ônus da prova, pelo qual o magistrado pode inverter o destino do encargo probatório em casos específicos, quando as peculiaridades da lide justificam um tratamento diferenciado como forma de proporcionar maior equilíbrio e justiça no âmbito da respectiva demanda;

E) Nos casos nos quais se discute a responsabilização subsidiária do tomador de serviços terceirizado no âmbito da administração pública, é plenamente aplicável o princípio 
da aptidão para a prova, por meio do qual o ônus de provar a inexistência de culpa in vigilando ou in eligendo do administrador público será do próprio, uma vez que apenas este reúne condições de demonstrar o cumprimento de seus deveres de observar o devido processo legal na contratação administrativa da empresa interposta, e de policiar a observância da legislação laboral por esta em face aos seus empregados;

F) Simplesmente não é razoável atribuir ao empregador/trabalhador o encargo de provar a regularidade do processo administrativo de contratação da empresa interposta ou a efetiva fiscalização por parte do administrador público acerca do cumprimento de obrigações laborais pela empresa interposta, uma vez que as respectivas provas se revelam impossíveis ou muito difíceis de produzir por parte do empregado autor, constituindo autênticos exemplos de "prova diabólica";

G) A atribuição ao administrador público do ônus de provar o correto cumprimento dos seus deveres de seguir o devido processo legal na contratação administrativa da empresa interposta e de fiscalizar o adimplemento das obrigações laborais desta é, essencialmente, uma técnica processual perfeitamente admissível e em plena sintonia com os valores constitucionais da dignidade da pessoa humana e do valor social do trabalho, bem como harmonioso com as garantias constitucionais do processo, correspondendo a uma importante ferramenta na busca por um modelo processual efetivo e apto a gerar uma tutela jurisdicional adequada, justa e útil.

H) Com a vigência do novo CPC, haverá maior segurança para os jurisdicionados, pois existirá base legal expressa para justificar a distribuição diferenciada do encargo probatório. Além disso, ao administrador público estará assegurado o direito de ter ciência de uma decisão fundamentada na qual restou definida tal repartição distinta e, ainda, o direito de ser proporcionada uma oportunidade para produzir as provas aptas para demonstrar se, de fato e de direito, houve ou não culpa do respectivo tomador de serviços terceirizados.

\section{REFERÊNCIAS}

BARROS, Alice Monteiro de. Curso de direito do trabalho. 4. ed. São Paulo: LTr, 2008.

DELGADO, Gabriela Neves. Terceirização: Paradoxo do direito do trabalho contemporâneo. São Paulo: LTr, 2003. 
DELGADO, Maurício Godinho. Curso de direito do trabalho. 10. ed. São Paulo: LTr, 2011.

DIDIER JR., Fredie; BRAGA, Paulo Sarno; e OLIVEIRA, Rafael Alexandria de. Curso de direito processual civil. V. 2: Teoria da prova, direito probatório, ações probatórias, decisão, precedente, coisa julgada e antecipação de tutela. 9. ed. Salvador: JusPodivm, 2014.

GARCIA, Gustavo Filipe Barbosa. Curso de direito do trabalho. 5. ed. Rio de Janeiro: Forense, 2011.

GIGLIO, Wagner. Direito processual do trabalho. 13. ed. São Paulo: Saraiva, 2003.

LEITE, Carlos Henrique Bezerra. Curso de direito processual do trabalho. 9. ed. São Paulo: LTr, 2011.

MACEDO, Lucas Buril de; e PEIXOTO, Ravi Medeiros. Ônus da prova e sua dinamização. Salvador: JusPodivm, 2014.

MARTINEZ, Luciano. Curso de direito do trabalho. 3. ed. São Paulo: Saraiva, 2012.

PAMPLONA FILHO, Rodolfo; e SOUZA, Tercio. Curso de direito processual do trabalho. São Paulo: Marcial Pons, 2013. 